Tropical Journal of Pharmaceutical Research February 2013; 12 (1): 71-76

ISSN: $1596-5996$ (print); 1596-9827 (electronic)

(c) Pharmacotherapy Group, Faculty of Pharmacy, University of Benin, Benin City, 300001 Nigeria.

All rights reserved.

Available online at http://www.tjpr.org

Original Research Article

http://dx.doi.org/10.4314/tjpr.v12i1.12

\title{
Phytochemical Screening and Cytotoxicity of Crude Extracts of Vatica diospyroides Symington Type LS
}

\author{
Theera Srisawat $^{1 *}$, Parinuch Chumkaew ${ }^{1}$, Waraporn Heed-Chim ${ }^{1}$, Yaowapa \\ Sukpondma ${ }^{2}$ and Kanyanatt Kanokwiroon ${ }^{3}$ \\ ${ }^{1}$ Faculty of Science and Industrial Technology, Prince of Songkla University Suratthani campus, Muang, Suratthani 84000 , \\ ${ }^{2}$ Department of Chemistry, Faculty of Science, ${ }^{3}$ Department of Biomedical Sciences, Faculty of Medicine, Prince of Songkla \\ University, Hat Yai, Songkhla 90110 Thailand
}

*For correspondence: E-mail: theera918s@hotmail.com, theera.s@psu.ac.th; Tel: +66-7735-5040 ext 8929; Fax: +66-77355453

Received: 18 October 2012

Revised accepted: 7 January 2013

\begin{abstract}
Purpose: To investigate the phytochemistry and cytotoxic activity of the leaf, branch and fruit extracts of Vatica diospyroides Symington type LS, an endangered medicinal plant in the peninsula of Thailand. Methods: Extracts of the mature leaves, branches and fruit (both cotyledon and pericarp) of five-year old tree were obtained using various organic solvents. Thin-layer chromatography (TLC) and phytochemical screening were employed to identify the chemical constituents. Cytotoxicity was characterized by $50 \%$ inhibition (IC $C_{50}$ ) of human breast cancer cell lines (MCF-7 and MDA-MB-468) using 3-(4,5-dimethylthaizol-2-yl)-2,5-diphenyltetrazolium bromide (MTT) assay.

Results: The extracts of the plant parts differed in chemical composition. Terpenoids and anthraquinones were present in all extracts, while cardiac glycosides and tannins were isolated from the branches and leaves, respectively. The acetone and methanol extracts of the fruit cotyledons were highly cytotoxic against MDA-MB-468 cell line ( $I C_{50}=3.1 \mu \mathrm{g} / \mathrm{ml}$ for both extracts), whereas acetone and dichloromethane extracts of the fruit pericarps were highly active against MCF-7 cell line $\left(I C_{50}=18.2\right.$ and $21.0 \mu \mathrm{g} / \mathrm{ml}$, respectively). The other extracts were less active.

Conclusion: This work revealed the potentials of $\mathrm{V}$. diospyroides fruit as a cytotoxic agent against human breast cancer cell lines. However, further studies, including identification and purification of the active compounds, will need to be pursued.
\end{abstract}

Keywords: Breast cancer, Crude extract, Dipterocarpaceae, MCF-7, MDA-MB-468, Vatica diospyroides

Tropical Journal of Pharmaceutical Research is indexed by Science Citation Index (SciSearch), Scopus, International Pharmaceutical Abstract, Chemical Abstracts, Embase, Index Copernicus, EBSCO, African Index Medicus, JournalSeek, Journal Citation Reports/Science Edition, Directory of Open Access Journals (DOAJ), African Journal Online, Bioline International, Open-J-Gate and Pharmacy Abstracts

\section{INTRODUCTION}

The family Dipterocarpaceae has many medicinal plants containing valuable curative compounds [1], such as genera Dipterocarpus, Shorea and Vatica [2]. In Thai ethnobotanical medicine, flowers and stems of the genus Vatica have been used as functional ingredients in cardiac and blood tonic remedies. Modern drug discovery research has shown that their stems contain resveratrol derivatives, namely Vaticaphenol A and Vaticanol series [3-5]. These resveratrol derivatives have been found to play an important role in cardiovascular treatment [6], and to be cytotoxic against various human cancer cell lines [3,5]. Resveratrol derivatives for human cancer chemoprevention are being tested in clinical research [7]. Therefore, the stems of plants in the genus Vatica not only provide traditional medicines like Thai cardiovascular 
tonics, but are currently supplied worldwide as cardioprotective and anticancer agents.

The stem of $V$. diospyroides Symington, an endemic medicinal and fragrant dipterocarp of Thailand peninsula, has strong anticancer activity [3,5]. However, other plant parts such as leaves have only been documented as having secondary compounds unlike the stem [8]. However, extracting the valuable phytochemical constituents of $V$. diospyroides from leaves, branches and fruits has not been reported to date.

Cancer is a leading cause of death worldwide and accounts for 7.6 million deaths especially in low-and middle-income countries. Invasive cancers such as those of lung, stomach, liver, colon/rectum, and breast, cause about $50 \%$ of all deaths [9]. Nowadays, plant secondary metabolites are accepted for use as anti-tumor agents, inhibiting the growth of human cancer cells. Most of the secondary compounds found in common medicinal plants are alkaloids, flavonoids and tannins [10]. The anti-cancer compounds, vinblastine and vincristine in common clinical use, are produced from genus Catharanthus, known in Thai as Phaeng phuai farang, and are sold in the U.S. market [1]. In a previous work [3], human oral epidermoid (KB), colon cancer (Col2), and breast cancer (BC1) cell lines were used in bioassay-guided fractionation of resveratrol tetramer, purified from the extract of $V$. diospyroides stem.

We had reported earlier that $V$. diospyroides can be classified into two distinct types of tree, namely the SS and LS forms [11]. It is reasonable to expect that these distinct types may have different activities against human cancer cells. The LS type is dominant in the population of Nong Thung Thong non-hunting area of Thailand, which may be the best genetic source of $V$. diospyroides. The present study aims to identify types of active constituents of various parts of the LS type of this plant and the cytotoxic activity of their extracts against human breast cancer cell lines (MCF-7 and MDA-MB468).

\section{EXPERIMENTAL}

\section{Plant materials and preparation of extracts}

Samples of the leaf, branch and fruit of $V$. diospyroides Symington type LS were collected from Nong Thung Thong non-hunting area, Kiansa, Suratthani Province, Thailand. Voucher specimens (Collector number T. Srisawat 001) were deposited in the Herbarium of Queen Sirikit
Botanic Garden (QBG), Maerim, Chiang Mai, Thailand. The samples were authenticated by Dr. Charun Maknoi of QBG.

The plant samples were cut into small pieces and completely air-dried, and stored in glass containers until extraction. About $270 \mathrm{~g}$ of the dried plant material was extracted for five days with n-hexane $\left(\mathrm{C}_{6} \mathrm{H}_{14}\right)$, dichloromethane $\left(\mathrm{CH}_{2} \mathrm{Cl}_{2}\right)$, methanol $\left(\mathrm{CH}_{3} \mathrm{OH}\right)$, or acetone $\left(\left(\mathrm{CH}_{3}\right)_{2} \mathrm{CO}\right)$. The extracts were filtered through 2 layers of cotton fabric. The extract of each sample was evaporated at room temperature, under reduced pressure, to the dry residue and stored in sterile vial pending phytochemical and cytotoxic screening.

\section{Phytochemical screening}

Tests for phytochemical constituents - Alkaloids, terpenoids, anthraquinones, flavonoids, saponins, and tannins - followed the methods described previously [8].

\section{Thin layer chromatography (TLC)}

Thin layer chromatography was applied to the extracts. The chromatograms were developed and dried on the silica gel TLC plates, and prior to spraying with vanillin-sulphuric acid, the spots visually observed under $U_{254}$ lamp to characterize various chemical components. The developing solvents used were ethyl acetate:nhexane (80:20 and 65:35), ethyl acetate:dichloromethane (85:15), dichloromethane:methanol $(80: 20)$, dichloromethane:nhexane $(85: 15)$ or $100 \%$ dichloromethane mixtures.

\section{In vitro cytotoxicity assay}

Cytotoxic activity was evaluated against human breast cancer cell lines. Cell cultures of MCF-7 $\left(\mathrm{HTB}-22^{\mathrm{TM}}\right.$ ) and MDA-MB-468 (HTB-132 ${ }^{\mathrm{TM}}$ ) were kindly provided by Assistant Professor Dr. Potchanapond Graidist. MCF-7 and MDA-MB468 were maintained in RPMI1640 and high glucose DMEM medium, respectively, supplemented with $10 \%$ fetal bovine serum and 100 units $/ \mathrm{ml}$ Penicillin-Streptomycin, in a humidified atmosphere with $5 \% \mathrm{CO}_{2}$ at $37{ }^{\circ} \mathrm{C}$. The cells were seeded in 96-well plates at a density of $2 \times 10^{4}$ cells (in $100 \mu$ l of medium) per well. The crude extracts were diluted to the desired concentration $(80,40,20,10$ and 5 $\mu \mathrm{g} / \mathrm{ml})$ in medium. The cultures were incubated for $72 \mathrm{~h}$ with the test extracts.

MTT assay was employed to determine cell viability. After $72 \mathrm{~h}$ of incubation, $100 \mu \mathrm{l}$ of 0.5 
$\mathrm{mg} / \mathrm{ml}$ MTT reagent was added into each well, and incubated for $30 \mathrm{~min}$ in a $\mathrm{CO}_{2}$ incubator. MTT solution was then discarded and $100 \mu \mathrm{l}$ dimethyl sulfoxide (DMSO) was added into each well to solubilize the cells and dissolve the color substance. For complete solubilization, the plates were vigorously agitated for $5 \mathrm{~min}$ at room temperature, and then read for optical density at $570 \mathrm{~nm}$ using a plate reader. A calibration curve based on optical density was constructed from which growth inhibition was determined. The 50 $\%$ growth inhibition concentrations $\left(\mathrm{IC}_{50}\right)$ of the extracts were calculated from fitted response curves. The cytotoxic activities of all the extracts against breast cancer cell lines were labeled according to the National Cancer Institute (NCl, USA) criteria (highly inhibiting activity means $\mathrm{IC}_{50}$ $\leq 20 \mu \mathrm{g} / \mathrm{ml}$ ) [12].

\section{RESULTS}

\section{Phytochemical constituents}

Phytochemical data (Table 1) show distinct patterns of chemical compositions in constituents of the extracts. The patterns of composition differed considerably in their quantitative values. The results of phytochemical evaluations are shown in Table 1. All the plant parts investigated were rich in terpenoids and anthraquinones whereas, alkaloids were absent. The n-hexane and methanol leaf extracts contained flavonoids, while only the n-hexane branch extract contained flavonoids was able to extract flavonoids from branches. Tannins and cardiac glycosides were present only in leaves and branches while terpenoids, anthraquinones and saponins were present in both pericarp and cotyledon extracts. Leaves and fruit contained saponins while branches did not.

\section{Chromatographical data}

Table 2 presents the Rate of flow $\left(R_{f}\right)$ values observed under $U_{254}$. The n-hexane leaf extract revealed 3 spots, and the branch extract 4 spots also, the dichloromethane branch extract presented 4 spots. Details of these and spots are contained in Table 2.

\section{In vitro cytotoxicity}

The criteria used to categorize the activity of $V$. diospyroides extracts against human breast cancer cell lines (MCF-7 and MDA-MB-468), based on $\mathrm{IC}_{50}$ values, were modified from those of $\mathrm{NCl}$ and Geran et al [12] as follows: $\mathrm{IC}_{50} \leq 20$ $\mu \mathrm{g} / \mathrm{ml}=$ highly active, $I_{50} 21-200 \mu \mathrm{g} / \mathrm{ml}=$ moderately active, $\mathrm{IC}_{50} 201-500 \mu \mathrm{g} / \mathrm{ml}=$ weakly active and $\mathrm{IC}_{50}>501 \mu \mathrm{g} / \mathrm{ml}=$ inactive. The cytotoxicity data for the fruit extracts against human breast cancer cell lines are displayed in Table 3.

Both acetone and methanol extracts of cotyledon were highly active $\left(\mathrm{IC}_{50}=3.1 \mu \mathrm{g} / \mathrm{ml}\right)$ against MDA-MB-468, but inactive and moderately active against MCF-7 ( $\mathrm{IC}_{50} 661.3$ and $90.6 \mu \mathrm{g} / \mathrm{ml}$, respectively). In contrast, both acetone and dichloromethane pericarp extracts were highly active against MCF-7 $\left(\mathrm{IC}_{50} 21.0\right.$ and $18.2 \mu \mathrm{g} / \mathrm{ml}$, respectively) but only moderately active against MDA-MB-468 $\left(\mathrm{IC}_{50} \quad 76.1\right.$ and $77.8 \mu \mathrm{g} / \mathrm{ml}$, respectively). The hexane and methanol branch extracts were moderately active $\left(\mathrm{IC}_{50} 69.3\right.$ and $94.2 \mu \mathrm{g} / \mathrm{ml}$, respectively), whereas the dichloromethane branch extract was inactive. All leaf extracts were inactive with undetectable $I_{50}$ levels.

\section{DISCUSSION}

Various active phytochemical compounds were found in the fruit, branch and leaf extracts of $V$. diospyroides Symington type LS. Terpenoids and anthraquinones were the major constituents found in all the extracts. These compounds have previously been reported as principal components of resveratrol derivatives in various extracts of medicinal herbs [13]. In general, the resveratrol compounds found in the stems of dipterocarpaceae are semipolar and polar [2],

Table 1 Phytochemical constituents of various solvent extracts of Vatica diospyroides type LS

\begin{tabular}{|c|c|c|c|c|c|c|c|c|c|c|}
\hline \multirow[t]{2}{*}{ Constituent } & \multicolumn{3}{|c|}{ Leaf } & \multicolumn{3}{|c|}{ Branch } & \multicolumn{2}{|c|}{ Pericarp } & \multicolumn{2}{|c|}{ Cotyledon } \\
\hline & $\mathbf{H}$ & D & $\mathbf{M}$ & $\mathbf{H}$ & D & $\mathbf{M}$ & $\mathbf{A}$ & D & $\mathbf{A}$ & $\mathbf{M}$ \\
\hline Terpenoids & + & - & + & + & + & - & - & + & + & + \\
\hline Alkaloids & - & - & - & - & - & - & - & - & - & - \\
\hline Anthraquinones & + & - & + & + & + & + & + & + & + & + \\
\hline Cardiac glycosides & - & - & - & + & - & + & - & - & - & - \\
\hline Flavonoids & + & - & + & + & - & - & - & - & - & - \\
\hline Tannins & - & - & + & - & - & - & - & - & - & - \\
\hline Saponins & + & + & + & - & - & - & + & + & + & - \\
\hline
\end{tabular}

Extract abbreviations: $\mathrm{H}=\mathrm{n}$-hexane; $\mathrm{D}=$ dichloromethane; $\mathrm{M}=$ methanol; $\mathrm{A}=$ acetone. $+=$ presence; $-=$ absence 
Table 2: TLC results $\left(R_{f}\right.$ value) for extracts of Vatica diospyroides type LS parts observed at $U_{254}$

\begin{tabular}{|c|c|c|c|c|c|c|c|c|c|c|}
\hline \multirow[t]{2}{*}{ Solvent ratio } & \multicolumn{3}{|c|}{ Leaf } & \multicolumn{3}{|c|}{ Branch } & \multicolumn{2}{|c|}{ Pericarp } & \multicolumn{2}{|c|}{ Cotyledon } \\
\hline & $H$ & $D$ & $M$ & $H$ & $D$ & $M$ & $\boldsymbol{A}$ & $D$ & $A$ & $M$ \\
\hline \multirow{4}{*}{$\begin{array}{l}\text { Dichloromethane (85\%): } \\
\text { n-hexane (15\%) }\end{array}$} & - & 0.03 & - & 0.15 & - & - & - & - & - & - \\
\hline & - & 0.36 & - & 0.37 & - & - & - & - & - & - \\
\hline & - & 0.15 & - & 0.57 & - & - & - & - & - & - \\
\hline & - & 0.93 & - & 0.84 & - & - & - & - & - & - \\
\hline \multirow{4}{*}{$\begin{array}{l}\text { Ethyl acetate }(65 \%) \text { : } \\
\text { n-hexane }(35 \%)\end{array}$} & 0.63 & - & - & - & 0.63 & - & - & - & - & - \\
\hline & 0.81 & - & - & - & 0.70 & - & - & - & - & - \\
\hline & 0.86 & - & - & - & 0.78 & - & - & - & - & - \\
\hline & - & - & - & - & 0.87 & - & - & - & - & - \\
\hline \multirow{3}{*}{$\begin{array}{l}\text { Dichloromethane (80\%): } \\
\text { Methanol }(20 \%)\end{array}$} & - & - & - & - & - & - & - & - & 0.12 & 0.12 \\
\hline & - & - & - & - & - & - & - & - & 0.20 & 0.20 \\
\hline & - & - & - & - & - & - & - & - & 0.32 & 0.32 \\
\hline \multirow[t]{2}{*}{ Dichloromethane (100\%) } & - & - & - & - & - & - & $0.45^{*}$ & $0.45^{*}$ & - & - \\
\hline & - & - & - & - & - & - & $0.71^{*}$ & $0.71^{*}$ & - & - \\
\hline Ethyl acetate (85\%): & - & - & - & - & - & 0.39 & - & - & - & - \\
\hline \multirow[t]{2}{*}{ Dichloromethane (15\%) } & - & - & - & - & - & 0.76 & - & - & - & - \\
\hline & - & - & - & - & - & 0.81 & - & - & - & - \\
\hline $\begin{array}{l}\text { Ethyl acetate }(80 \%) \text { : } \\
\text { n-hexane }(20 \%)\end{array}$ & - & - & 0.88 & - & - & - & - & - & - & - \\
\hline
\end{tabular}

Table 3: Cytotoxic activity $\left(\mathrm{IC}_{50}\right)$ of fruit extracts of Vatica diospyroides type LS

\begin{tabular}{|c|c|c|c|}
\hline \multirow[b]{2}{*}{ Fruit part } & \multirow[b]{2}{*}{ Extract } & \multicolumn{2}{|c|}{ Cytotoxic activity $\left(\mathrm{IC}_{50}, \mu \mathrm{g} / \mathrm{ml}\right)$} \\
\hline & & MCF-7 & MDA-MB-468 \\
\hline \multirow[t]{2}{*}{ Cotyledon } & Acetone & 661.3 & $3.1^{\star *}$ \\
\hline & Methanol & 90.6 & $3.1^{* *}$ \\
\hline \multirow[t]{2}{*}{ Pericarp } & Acetone & $21.0^{*}$ & 76.1 \\
\hline & Dichloromethane & $18.2^{*}$ & 77.8 \\
\hline
\end{tabular}

and extracting these from the leaves, branches and fruit of $V$. diospyroides require polar or highly polar solvents. Our results also indicate acetone and methanol are the best solvents for extraction, in terms of quantitative and cytotoxic properties of the extracts.

On the other hand, alkaloids were absent from all the extracts. The non-existence of alkaloids in $V$. diospyroides is a deviation from several other medicinal plants [10]. Alkaloids are commonly found in most medicinal plants, and they have various useful bioactivities which favours their use as active ingredients in anti-inflammatory medications [14]. In addition, they are widely used for treating various cancers [1] and malaria [15]. Previously, the cardioprotective effect of alkaloids from other plants in dipterocarpaceae family has been described [6]. Thus, if indeed $V$. diospyroides extracts has prophylactic cardiovascular effect, this is likely to be due to non-alkaloidal compounds.

Interestingly, cardiac glycosides were only present in the branch extract. Cardiac glycosides have been found in a number of plants used in blood tonics for treating heart failure via blood pressure regulation [16]. This may lend some support for the use of $V$. diospyroides stem extract in classic Thai blood tonic. Tannin, however, was present only in the leaf extract while saponin was absent only from only the branch extracts. Flavonoids, which were present both in leaf and branch extracts, are antioxidants with cardiovascular prevention and anticancer properties $[1,2,17]$.

The anticancer activities of terpenoids, saponins, cardiac glycosides and anthraquinones have been reported for various plant extracts $[10,18,19]$. Terpenoids and saponins are biologically active against various human cancer cell lines [19]. Similarly, these compounds are potent against human breast cancer cell lines. However, these secondary metabolites exert their anticancer activity through different mechanisms. Carvalho et al [20] reported that plant extracts can decrease cell proteins, alter cell morphology, and fragment nucleosomal DNA of cancer cells, resulting in cell apoptosis. Therefore cardiac glycosides may induce immunogenic cancer cell death. 
The human breast carcinoma cell lines used in this study - MCF-7 and MDA-MB-468 - are in common laboratory use. A high cytotoxic activity against MCF-7 was observed for acetone and dichloromethane extracts of pericarp, whereas the acetone and methanol extracts of cotyledon were highly active against MDA-MB-468. Thus each extract is a different cocktail of ingredients with potential activity that is specific to a particular cell line. This is not unexpected since MCF-7 is a luminal cancer cell line representing low tumor grade. In contrast, the basal-like carcinoma cell line, MDA-MB-468, represents a high tumor grade, and is triple negative for the immunophenotypic markers ER/PGR ${ }^{-} / \mathrm{HER}^{-}$. MDA-MB-468 was expectedly more sensitive to the extracts and culture conditions than MCF-7. High cell proliferation of MDA-MB-468 corresponds to a poor prognosis.

Fruit extracts of other medicinal plants, e.g., some compounds produced from the seed kernels of the Thai medicinal plant, Entada rheedei Sprengel, have been evaluated against various human cancer cell lines [17]. However, the fruit extracts of $V$. diospyroides have not previously been described and reported in Thai ethnopharmacology, and the active components have not been identified. The current study is the first to demonstrate that the highly active constituents of the fruit extracts inhibit breast cancer cells.

No normal human cells were tested in this study, and cultured immortalized cell lines will not behave as they would in vivo. While in vitro toxicology may sound attractive, there is a view that it is currently unrealistic. Our findings have indicated that fruit extracts of $V$. diospyroides may be worth further investigation with a view to isolating the active compounds.

\section{CONCLUSION}

This work demonstrates that $V$. diospyroides fruit extracts have pharmacological potential. The pericarp and cotyledon extracts of this plant inhibit the growth of MCF-7 and MDA-MB-468, on a highly active level. Further studies are planned to identify and purify the in vitro active compounds for subsequent in vivo evaluation.

\section{ACKNOWLEDGEMENT}

This work was financially supported, in part, by Prince of Songkla University. The authors thank Assistant Professor Dr. Potchanapond Graidist for providing cancer cell lines and Associate Professor Dr. Seppo Karrila for his helpful comments and suggestions.

\section{REFERENCES}

1. Kinghorn $A D$, Cui $B$, Ito $A$, Chung HS, Seo EK, Long $L$, Chang LC. Fractionation of plants to discover substances to combat cancer. In: Biologically active natural products: Pharmaceuticals. Cutler SJ, Cutler HG (Eds). CRC Press LLC. Florida, United State of America; 2000; pp 16-23.

2. Wan Mohd Zain WZ, Ahmat N, Norizan NH, Atikah Mohd Nazri NA. The evaluation of antioxidant, antibacterial and structural identification activity of trimer resveratrol from Malaysia's dipterocaparceae. Aust J Basic Appl Sci 2011; 5: 926-929.

3. Seo EK, Chai, H, Constant HL, Santisuk T, Reutrakul V, Beecher CWW, Farnsworth NR, Cordell GA, Pezzuto JM, Kinghorn AD. Resveratrol tetramers from Vatica diospyroides. J Org Chem 1999; 64: 6976-6983.

4. Ito T, Akao Y, Yi H, Ohguchi K, Matsumoto K, Tanaka T, linoma $M$, Nozawa $Y$. Antitumor effect of resveratrol oligomers against human cancer cell lines and the molecular mechanism of apoptosis induced by Vaticanol C. Carcinogenesis 2003; 24: 1489-1497.

5. Kinghorn AD, Pan L, Fletcher JN, Chai $H$. The relevance of higher plants in lead compound discovery programs. J Nat Prod 2011; 74: 1539-1555.

6. Wu JM, Hsieh TC, Wang Z. Cardioprotection by resveratrol: a review of effects/targets in cultured cells and animal tissues. Am J Cardiovasc Dis 2011; 1: 38-47.

7. Athar M, Back JH, Tang X, Kim KH, Kopelovich L, Bickers $D R$, Kim AL. Resveratrol: A review of pre-clinical studies for human cancer prevention. Toxicol Appl Pharmacol 2007; 224 (3): 274-283.

8. Kamba AS, Hassan LG. Phytochemical screening and antimicrobial activities of Euphorbia balsamifera leaves, stems and root against some pathogenic microorganisms. Afr J Pharm Pharmacol 2010; 4: 645-652.

9. World Health Organization. Cancer. http://www.who.int/ mediacentre/factsheets/fs297/en/ 2012; Accessed on 2012/02/21.

10. Edeoga HO, Okwu DE, Mbaebie BO. Phytochemical constituents of some Nigerian medicinal plants. Afr J Biotechnol 2005; 4: 685-688.

11. Srisawat T, Thipnetr S, Maknoi C. A preliminary study of leaf morphology and flow cytometry in the Vatica diospyroides Symington, endangered medicinal plant of Peninsular Thailand. J Med Plant Res 2012; 6(20): 3456-3466.

12. Geran Rl, Greenberg NH, Macdonald MM, Shumacher AM, Abbott BJ. Protocols for screening chemical agents and natural products against animal tumors and other biological systems. Cancer Chemotherapy Reports, Part III, 1972; 3: 1-103.

13. Cai $Y$, Luo $Q$, Sun M, Corke $H$. Antioxidant activity and phenolic compounds of 112 traditional Chinese medicinal plants associated with anticancer. Life Sci 2004; 74: 2157-2184.

14. Barbosa-Filho JM, Piuvezum MR, Moura MD, Silva MS, Batista Lima KV, Leitao da-Cunha, Fechine IM, Takemura OS. Anti-inflammatory activity of alkaloids: A twenty century review. Braz J Pharmacogn 2006; 16 (1): 109-139.

15. Francois G, Timperman G, Eling W, Ake Assi L, Holenz J, Bringmann G. Naphthylisoquinoline alkaloids against malaria: Evaluation of the curative potentials of Dioncophylline $C$ and Dioncopeltine $A$ against Plasmodium berghei in vivo. Antimicrob Agents Ch 1997; 41 (11): 2533-2539.

16. Schoner $W$, Scheiner-Bibis G. Endogenous and exogenous cardiac glycosides: their roles in 
hypertension, salt metabolism and cell growth. Am J Physiol Cell Physiol 2007; 293: C509-C536.

17. Sugimoto S, Matsunami K, Otsuka H. Medicinal plant of Thailand. II: chemical studies on the seed kernels of Entada rheedei Sprengel. J Nat Med 2012; 66 (3): 552-557.

18. Menger L, Vacchelli E, Adjemian S, Martins I, Ma Y, Shen $S$, Yamazaki $T$, Sukkurwala $A Q$, Michaud $M$, Mignot $G$ et al. Cardiac glycosides exert anticancer effects by inducing immunogenic cell death. Sci Transl Med 2012; 4: 143ra99.
19. Zhang Z, Li S. Cytotoxic triterpenoid saponins from the fruits of Aesculus pavia L. Phytochemistry. 2007; 68: 2075-2086.

20. Carvalho AJS, Ishikawa T, Gouvea CMCP. Aqueous extract of Plinia edulis leaves: Antioxidant activity and cytotoxicity to human breast cancer MCF-7 cell line. S Afr J Bot 2012; 81: 1-7. 